\title{
Perbandingan Karakteristik Pola Penyediaan Infrastruktur Permukiman Padat Tinggi Dan Rendah Kasus di Danakusuman Dan Mojosongo Kota Surakarta
}

\author{
Wahyu Putri N.I.S, Kuswanto Nurhadi, Isti Andini \\ Program Studi Perencanaan Wilayah dan Kota, \\ Jurusan Arsitektur, Fakultas Teknik \\ Universitas Sebelas Maret, Surakarta \\ email: wepeputrii@yahoo.co.id
}

\begin{abstract}
Surakarta has five subdistrict. Subdistrict with the highest density is Serengan and subdistrict with the lowest density is Jebres. In Serengan, Danukusuman is the crowded, whereas in Jebres, Mojosongo is the lowest density. Density differences problem can result in differences in the activity of the people who live. Then can affect the differences in infrastructure needs and patterns of settlement there is the provision of infrastructure (actor variations and details of cooperation). So, this study done to know the characteristic comparison of high and low density settlements infrastructure provision pattern in Danukusuman and Mojosongo. To gain it, carried out was used a comparative analysis of settlement characteristics both in terms of physical, economic and socio-cultural. further analysis is to compare the characteristics of the infrastructure available with the applicable standards (SNI). then, final analysis is to determine and compare the pattern of provision of infrastructure and settlements in Danukusuman and Mojosongo. the results of the analysis is known that that there was no significant difference between high dense settlements (Danukusuman) and low dense settlements (Mojosongo) both from the aspect of the character of the location, infrastructure preparation and provision pattern. Only difference is quite prominent at the level of the economy and the provision of communal wastewater infrastructure that influenced by the density of settlement, while the difference in the provision of clean water is more influenced by the character of the location / the physical settlement.
\end{abstract}

Keywords: high and low density, pattern of provision of infrastructure settlement infrastructure,

\section{PENDAHULUAN}

Permukiman mempunyai peran penting dalam sistem kota sebagai kawasan fungsional yang ditunjang oleh ketersediaan infrastrukturnya (Pratikto, 2008). Permukiman penduduk dibedakan menjadi empat sesuai kepadatannya yaitu sangat padat, padat tinggi, sedang dan padat rendah (SNI 03-1733-2004). Perbedaan kepadatan permukiman dipengaruhi oleh faktor geografis, ekonomi, sosial dan budaya. Kepadatan permukiman penduduk yang berbeda-beda mengakibatkan perbedaan pola kegiatan pada masyarakat. Wijiastuti dan Kurniati (2012) menyebutkan bahwa pola kegiatan masyarakat meliputi pola ekonomi, sosial, kebudayaan maupun pola keagaman. Perbedaan ini menimbulkan perbedaan karakter kebutuhan infrastuktur pemukiman yang harus dipenuhi. Perbedaan karakter kebutuhan infrastruktur yang berbeda untuk setiap pola kegiatannya dapat mengakibatkan perbedaan pola penyediaan infrastruktur permukiman di daerah satu dan daerah lainnya.

Kota Surakarta memiliki luasan lahan perumahan permukiman yaitu $2874,93 \mathrm{~km}^{2}$ atau 65,28\% dari luas wilayahnya (Surakarta Dalam Angka, 2014). Dari data tersebut juga dinyatakan bahwa kecamatan yang mempunyai kepadatan penduduk paling tinggi adalah Serengan, sedangkan yang mempunyai kepadatan paling rendah adalah Kecamatan Mojosongo.

Di Kecamatan Serengan (padat sedang) terdapat satu wilayah yang mempunyai kepadatan penduduk tertinggi yaitu Kelurahan Danukusuman (233,68 jiwa/ha). Sedangkan di Kecamatan Jebres (padat rendah) terdapat satu wilayah yang 
mempunyai kepadatan terendah yaitu Kelurahan Mojosongo. Kedua wilyah ini mempunyai pola kegiatan permukiman yang berbeda.

Perbedaan karakter kebutuhan infrastruktur permukiman yang ada di permukiman kepadatan tinggi dan rendah berimbas pada perbedaan pola penyediaan inrastrukturnya. Oleh karena itu, perbedaan kepadatan penduduk dapat menyebabkan pola penyediaan infrastruktur yang berbeda di setiap permukiman yang berbeda kepadatannya. Perbedaan pola penyediaan infrastruktur yang dimaksud bisa dari variasi peran aktor baik pemerintah, swasta maupun masyarakat sendiri atau dari peran aktor terkait, jenis infrastruktur yang dikerjasamakan atau dari jangka waktu komersial kerjasama tersebut. Menurut Susanto (2008), terdapat 7 pola kerjasama pemerintah swasta (KPS), tetapi induknya berasal dari BOT (Build Operate Transfer) dan atau BOOT (Build Operate Own Transfer).

Untuk mengetahui karakteristik penyediaan infrastruktur permukiman di dua permukiman dengan kepadatan yang berbeda digunakan Standar Nasional Indonesia (SNI) dengan dipadukan pola kegiatan masyarakat yang ada. Dengan mengetahui karakteristik penyediaan infrastruktur permukiman baik untuk kepadatan tinggi maupun rendah, perbedaan antara keduanya dapat dianalisis baik mengenai ketersediaan, manajemen penyediaan maupun aktor yang terlibat dalam penyediannya. Pemahaman mengenai perbedaan ini menegaskan kembali pengaruh kepadatan permukiman dalam penyediaan infrastruktur permukiman. Oleh karena itu, tujuan dari penelitian ini adalah untuk mengidentifikasi perbedaan karakteristik pola penyediaan infrastruktur pada permukiman di Kelurahan Danukusuman (kepadatan tinggi) dan Mojosongo (kepadatan rendah).

\section{METODE}

\subsection{Ruang Lingkup}

Ruang lingkup wilayah penelitian yaitu permukiman di Kelurahan Danukusuman dan Mojosongo. Terdapat 5 (lima) RW dengan kepadatan tinggi di Danukusuman, sedangkan di Kelurahan Mojosongo terdapat $21 \mathrm{RW}$ dengan kepadatan rendah. Indikator yang digunakan dalam penelitian ini dibatasi pada karakteristik pola penyediaan infrastruktur permukiman di Kelurahan Danukusuman dan Mojosongo. Karaktersitik yang dimaksud adalah pola dalam pengadaan jaringan-jaringan pelayanan yang mendukung kegiatan bermasyarakat dalam area tersebut seperti jaringan jalan, jaringan air bersih, drainase, sanitasi dan persampahan serta variasi aktor yang berperan dalam penyediaan infrastruktur di sana.

\subsection{Metode Analisis}

Penelitian ini menggunakan metode analisa perbandingan (comparison) yang merupakan suatu teknik analisis dengan cara membandingkan unsur dalam wilayah A dengan wilayah B atau lebih. Berikut langkah-langkah dalam analisis penelitian ini :

1. Mengidentifikasi karakteristik permukiman padat tinggi dan rendah yaitu di Kelurahan Danukusuman dan Mojosongo.

2. Mengidentifikasi karakter insfrastruktur yang tersedia dengan standar yang berlaku (SNI Permukiman Perkotaan).

3. Mengetahui karakteristik pola penyediaan infrastruktur permukiman di Kelurahan Danukusuman dan Mojosongo.

4. Menganalisis perbedaan pola penyediaan infrastruktur permukiman di Kelurahan Danukusuman dan Mojosongo

\section{HASIL DAN PEMBAHASAN}

\subsection{Perbandingan Karakter Permukiman}

Analisis perbandingan karakter permukiman merupakan analisis yang bertujuan untuk memperoleh perbandingan karakteristik masing-masing permukiman baik dari segi fisik, ekonomi maupun sosial budaya.

Metode yang digunakan dalam analisis ini yaitu analisis deskriptif untuk masingmasing lokasi kemudian dilakukan analisis perbandingan.

Analisis perbandingan karakteristik permukiman ini menggunakan data primer 
baik dari responden sampel maupun narasumber terpilih.

Perumusan jumlah responden adalah sebagai berikut :

$\mathrm{n}=\mathbf{N}:\left(1+\mathbf{N} \cdot \mathrm{e}^{2}\right)$,

$\mathrm{n}=$ jumlah sampel

$\mathrm{N}=$ Populasi rumah

$\mathrm{e}=$ batas toleransi kesalahan

Dari perumusan tersebut didapatkan hasil total responden adalah 372 rumah dengan rincian 157 rumah di Danukusuman dan 215 rumah di Mojosongo. Berikut hasil analisis perbandingan karakteristik permukiman Danukusuman dan Mojosongo :

1. Kedua lokasi mempunyai karakter fisik yang sama, akan tetapi menunjukkan kepadatan yang berbeda. Perbedaan karakter ekonomi cukup signifikan ditunjukkan pada pendapatan penduduk yang di bawah UMR di mana kedua wilayah mempunyai selisih $17 \%$. Hal ini dapat ditarik kesimpulan bahwa semakin padat suatu permukiman maka semakin berkurang kesejahteraannya.

2. Kegiatan masyarakat yang terjadi kedua permukiman tersebut dapat dikatakan relatif sama. Dengan demikian kebutuhan akan infrasruktur permukiman juga hampir sama walaupun kepadatan dan kesejahteraan penduduknya sedikit berbeda. Namun, kapasitas penyediaan berbeda antara satu lokasi dengan lokasi lainnya.

\subsection{Analisis Karakteristik Infrastruktur Permukiman}

3.2.1 Infrastruktur Jalan dan Transportasi Lokal

Di kedua wilayah penelitian dapat dikatakan mempunyai karakteristik infrastruktur jalan dan transportasi lokal yang hampir sama. Namun, terdapat perbedaan dalam ketersediaan tempat pemberhentian bis. Padahal tempat pemberhentian sangat membantu memudahkan masyarakat dalam mengakses angkutan umum (bis).

\subsubsection{Infrastruktur Drainase}

Kebutuhan akan jaringan drainase di kedua wilayah tidak terlalu berbeda. Perbedaan kebutuhan tersebut dapat disebabkan oleh perbedaan karakter lokasi (kelerengan dan kemiringan) yang menyebabkan potensi bencana banjir/genangan di Kelurahan Danukusuman karena berada di dataran rendah. Namun, hasil analisis tidak menunjukkan adanya penyediaan pompa air yang seharusnya disiapkan ketika suatu daerah tergenang air.

\subsubsection{Infrastruktur Air Bersih}

Kebutuhan air bersih baik di Danukusuman dan Mojosongo masih dapat terpenuhi dengan baik oleh PDAM maupun sumur warga. Perbedaan ditemukan dalam sistem penyediaan infrastruktur tersebut di mana sebagian permukiman di Mojosongo menggunakan suplai air tangki PDAM. Hal ini dikarenakan daerah tersebut mempunyai karakter lokasi (ketinggian) yang mengakibatkan sedikit sulit mendapatkan air layak minum.

\subsubsection{Infrastruktur Air Limbah}

Kegiatan bermukim yang lebih lama menyebabkan lebih besarnya limbah yang dihasilkan masyarakat. Untuk kebutuhan septic tank, sebagian besar masyarakat sudah memiliki kakus pribadi dan septic tank, tetapi belum tersedianya bidang resapan di lingkungan permukiman. Ditemukan perbedaan pada unsur jaringan pemipaan air limbah. Karena minimnya lahan (karakter lokasi kepadatan), wilayah Danukusuman belum mampu menyediakan IPAL Komunal mandiri walaupun sebenarnya kebutuhan akan infrastruktur ini cukup tinggi mengingat kegiatan industri yang cukup tersebar di Danukusuman. Hal ini berbeda dengan wilayah Mojosongo yang masih mempunyai cukup lahan dalam penyediaan IPAL Komunal untuk memenuhi kebutuhan warga sekitar

\subsubsection{Infrastruktur Persampahan}

Banyaknya limbah padat (sampah) yang dihasilkan masyarakat sudah dapat teratasi dengan ketersediaan tempat sampah dan pengangkutannya ke TPS. Namun, terdapat perbedaan 
mengenai syarat jarak TPS dengan hunian/ permukiman. TPS Danukusuman belum memenuhi syarat SNI dikarenakan jarak TPSnya $<30 \mathrm{~m}$. Dari analisis yang telah dilakukan, ditemukan perbedaan pada karakter sediaan infrastruktur transportasi lokal (tempat pemberhentian bis), air bersih (tangki air) dan air limbah (IPAL Komunal). Padahal apabila melihat karakter kebutuhan berdasar kegiatan masyarakat yang ditunjukkan tidak terlalu berbeda.

\subsection{Analisis Perbandingan Pola Penyediaan Infrastruktur}

3.3.1 Pola Penyediaan Sistem Jalan dan Transportasi Lokal

Dalam penyediaan jalan dan transportasi lokal di kedua lokasi penelitian, tidak ditemukan perbedaan yang signifikan. Terdapat keterlibatan masyarakat, pemerintah dan swasta dalam penyediaan infrastruktur ini. Tidak ditemukan pola KPS (Kerjasama Pemerintah Swasta), tetapi muncul pola pemberdayaan masyarakat dalam bidang pemeliharaan infrastruktur.

\subsubsection{Pola Penyediaan Sistem Drainase}

Penyediaan drainase di kedua lokasi penelitian sebagian besar merupakan program pemerintah melalui DPU. Tidak ditemukan keterlibatan pihak swasta maupun KPS dalam infrastruktur ini, tetapi terdapat pola pemberdayaan masyarakat dalam pemeliharaan jaringan drainase tersier (selokan).

\subsubsection{Pola Penyediaan Sistem Air Bersih}

Penyediaan dan pemeliharaan air bersih dilakukan oleh pemerintah (PDAM) dan masyarakat. Oleh karena itu, tidak ditemukan pola KPS dalam bentuk lain, hanya terdapat pola pemberdayaan masyarakat dalam pemeliharan infrastruktur ini.

\subsubsection{Pola Penyediaan Sistem Air Limbah}

Secara umum infrastruktur air limbah disediakan oleh pemerintah setempat (DPU). Tidak ditemukan keterlibatan pihak swasta, sehingga tidak terdapat pola KPS dalam penyediaan infrastruktur ini. Sedangkan keterlibatan masyarakat hanya dalam bentuk pemeliharaan septic tank dan Sanimas (Sanitasi Masyarakat).

\subsubsection{Pola penyediaan Persampahan}

Penyediaan infrastruktur persampahan dilakukan oleh pemerintah bersama dengan masyarakat. Tidak ditemukan keterlibatan pihak swasta, sehingga tidak terdapat pola KPS dalam infrastruktur ini.

Dari analisis yang telah dilakukan dapat disimpulkan bahwa tingkat keterlibatan aktor-aktor dalam penyediaan infrastruktur adalah sama di kedua lokasi penelitian. Namun, apabila dikaitkan dengan kegiatan sosial dan tingkat ekonomi masyarakat akan muncul perbedaan mengenai proyek penyediaan yang terjadi. Tingkat ekonomi di Danukusuman lebih rendah apabila dibandingkan dengan Mojsosongo, sehingga lebih banyak program penyediaan infrastruktur oleh pemerintah yang tidak ditemukan di Mojosongo, yaitu Sanimas dan pavingisasi.

\section{KESIMPULAN}

Tidak ditemukan perbedaan pola penyediaan infrastrukutr yang mencolok untuk kedua lokasi penelitian. Padahal keterlibatan aktor dalam penyediaan infrastruktur dapat diipengaruhi oleh kegiatan sosial masyarakatnya, tetapi hal ini tidak terbukti. Perbedaan pola penyediaan infrastruktur ditunjukkan dari ragam objek penyediaan yang sedikit berbeda antara permukiman padat tinggi (Danukusuman) dan padat rendah (Mojosongo). Diketahui bahwa lebih banyak program penyediaan infrastruktur di Danukusuman yang mempunyai tingkat ekonomi lebih rendah dibanding Mojosongo.

Jadi, dapat disimpulkan bahwa tidak terdapat perbedaan yang cukup signifikan antara permukiman padat tinggi (Danukusuman) dan padat rendah (Mojosongo) baik dari aspek karakter lokasi, sediaan infrastruktur dan pola penyediaannya. Hanya saja perbedaan cukup menonjol pada tingkat perekonomian dan penyediaan 
infrastruktur IPAL Komunal yang secara langsung dipengaruhi oleh kepadatan permukiman, sedangkan perbedaan pada penyediaan air bersih lebih dipengaruhi oleh karakter lokasi/fisik permukiman tersebut

\section{REFERENSI}

Pratikto, Hawik Henry. 2008. Preferensi Konsumen Perumahan Terhadap Kondisi Fisik Dan Ketersediaan Infrastruktur. Semarang : Universitas Diponegoro

SNI 03-1733-2004 tentang Tata cara perencanaan lingkungan perumahan di perkotaan.

SNI Pd-T-03-2005-C tentang Pedoman Pemilihan Kawasan Prioritas Permukiman.

Surakarta Dalam Angka. 2014

Susanto, Budi. 2008. Aspek Hukum Pembiayaan Proyek Infrastruktur dengan Model BOT. Genta Press

Wijiastuti, Alhamida Wahyu dan Kurniati, Rina (2012) Pengaruh Pola Aktivitas Penduduk Terhadap Perubahan Fungsi Jaringan Jalan Di Kawasan Kauman Kota Semarang. Semarang : Universitas Diponegoro 